\title{
Legal System Governing on Water Pollution in Iran
}

\author{
Flora Heidari ${ }^{*}$, Farhad Dabiri ${ }^{1}$, Mehdi Heidari $^{2}$ \\ ${ }^{1}$ Department of Environmental Law, Faculty of Environment and Energy, Islamic Azad University, Tehran Science and Research \\ Branch, Tehran, Iran \\ ${ }^{2}$ Department of Building, Civil and Environment, University of Concordia, Montreal, Canada \\ Email: floraheidari@yahoo.com,fara_dabiri@yahoo.com,mehdiheidari_1364@yahoo.com
}

How to cite this paper: Heidari, F., Dabiri, F. and Heidari, M. (2017) Legal System Governing on Water Pollution in Iran. Journal of Geoscience and Environment Protection, 5, 36-59.

https://doi.org/10.4236/gep.2017.59004

Received: June 28, 2017

Accepted: August 20, 2017

Published: August 23, 2017

Copyright (c) 2017 by authors and Scientific Research Publishing Inc. This work is licensed under the Creative Commons Attribution International License (CC BY 4.0).

http://creativecommons.org/licenses/by/4.0/

(c) (i) Open Access

\begin{abstract}
In the present era, water contamination represents one of the considerable environmental problems. Population growth along with ever increasing industrial developments has resulted in the contamination of most of the water resources in the world, bringing about serious problems for humans and other living organisms. According to the human life on earth depends on the way different water resources are exploited, the most important way to preserve the quality of water resources is to codify appropriate regulations and standards and develop plans for proper and principled implementation of them. Therefore, it seems to be necessary to take required actions to manage water resources optimally. In this regard, one of the most significant legal tools is the law. Following a descriptive-analytic approach, the present research aims to consider legal challenges in the context of water contamination briefly. Investigations indicate that, given the limitations in water resources, in future, water contamination will raise serious problems for the country should the solutions and measures required for tackling this issue are not well incorporated into respective regulations. As such, in order to systemize the activities within this scope, it is necessary to codify a comprehensive act about different water-related topics, so as to cover all separate and sparse pieces of regulations on water. Further, acquiring help from experts when preparing the regulations with an emphasis on the inhibitory role of penalties, roles of NGOs and culture-making in the society will contribute to the successful legal protection of the quality of water resources.
\end{abstract}

\section{Keywords}

Water Contamination, Water Law, Legal Challenges, Rules and Regulations, Sanction 


\section{Introduction}

The environment is assumed as one of the necessary pillars of life and development since it plays several roles in establishing balance in various life constituents. In cause-and-effect world where the nature is an effect of divine beauty with different forms and variety of life and an integrated group in which the elements and resources mutually affect each other and under mandatory and coercive rules many of them comprise of undiscovered mysteries, it creates finally balance along with this cause and effect relationship [1]. The environment has been defined as a setting which involves the process of living while also, interacting with it. And it is built on nature, human society and the environment made by human hands and thoughts. Also, it includes all the living space on the earth [2], but today due to lack of specific rules and regulations and lack of definition of exclusive proprietorship that has been freely and unlimitedly exploited by the human and consequently it is led to creation of various contaminations in the environment and destruction in this area [3]. Water covers one of the most crucial areas of the environment on which the human is dependent since approximately seventy-one percent of earth planet. This element is the secret for world survival and one of the main components for survival and duration of the life cycle in the land planet. The historical sources suggest that the water and irrigation have been deemed as much essential in Persia. In addition to divine nature and the respect they attached for water, they have also invented the best irrigations techniques. Of yore, Iranian people constructed dams and irrigation canals. The most ancient method of irrigation is called aqueduct the Iranians created it. Following to advent of clear Islamic religion, the water, which was considered as capital for the tribes, enjoyed the particular position and assumed as public properties and belonged to all Muslims [1]. Similarly, in Holy Quran, water has been indicated as the most valuable creature of Almighty God after humans, and there are more than one hundred verses in Holy Quran concerning this subject. The proper use and helping to protect from water against any contamination deemed as one of the thanksgiving dimensions. The divine bounties are some deposits Almighty God has put at the disposal of humans for development and excellence. Thus, exploitation of them should be in coordination with divine commands and toward the eternal salvation of human beings. At present this bounty has unfortunately subject to types of environmental pollutants and the diseases caused by water pollution is one of the main reasons for mortalities [4]. About slow trend of mixture process and transformation of pollutant materials entering in water, contamination of water is removed very longer than other pollutants. With respect of water circulation in nature it is seen that if a matter or materials are added to the water, it is circulated in nature along with water and the given material(s) is hazardous for health of animals or humans or causes imbalance in ecosystems, it will be followed by irrecoverable losses [5].

For the geographical situation of Iran on earth and also due to the exceptional condition of the low and high lands and the shortage of precipitations, particu- 
larly at the center and south of Iran, this has caused Iran to be assumed as one of the arid or semi-arid zones in the world [6]. The subject of water supplies is proposed as one of the issues with particular importance on the scene of national domestic policy and the necessity for protection and prevention from contamination becomes more evident in the aquatic environmental scene than ever.

\subsection{Water in Environment}

About $97.5 \%$ of existing water in environment is found as saline subterranean waters in oceans and the rest $2.5 \%$ includes fresh water out of which $2 / 3(1.76 \%$ of total water) is entrapped in iceboxes and snow coverage and the rest 1.3 ( $0.77 \%$ of total water) comprises of underground freshwater, lakes, rivers, and also soil humidity, and biologic and atmospheric waters. Out of this part, only small portion of subterranean waters, water in rivers and lakes are available to the humans. The extractable underground water constitutes almost all freshwater while the rivers and lakes are deemed as the main supplies for human consumption [7] [8] [9] and with respect to climatic and geographical conditions and based on rainfall rate it includes dry, seasonal, and permanent streams [10]. The noticeable feature of freshwater lies in their structure in water basin that has been restricted by natural borders called drainage field or division. Any change in some factors e.g. climate, geology, topography, soil, flora and fauna naturally and by activities of the human such as a change in use may affect in total watercourse system by the change in volume, the rate of current, water discharge, sedimentation rate and quality of water [11] [12].

Despite plenty of water deposits in the world, what it caused the status of freshwater supplies to become more crucial than in the past is the heterogeneous distribution of water among and or even inside the countries. On the other hand, the natural factors such as rain shortage, high evaporation, drought and human causes including population growth, urban development, and agricultural irrigation are also involved in descending trend of freshwater supplies. Thus, on the status quo, the countries should try to protect and optimize useful consumptions of their natural water supplies.

\subsection{Water Resources Management}

Over the history of human life, administration services for water supplies have been widely deemed as important in the development of communities. The importance of these services may be so far tangible and assessed by ancient communities. Those humans, who lived with earliest civilizations in arid and semiarid areas, should be informed about water and dominance over it thereby to get rid of continual roaming and to achieve stability and security in permanent habitats. Following to inadvertent growth of population in the twentieth century and particularly in the second half of this century, the rate of services and activities of water supply management reached to an unprecedented level by spending billion dollars of cost. Such measures are not practical without financing and 
sponsorship of domestic and foreign governments and institutions as well as conducting extensive investments. The current system for management and exploitation of water supplies has started the formation phases under the effect of historical conditions and social changes of Iran since about 70 years ago. Due to the discordant growth of population and the given establishment pattern during this period, urbanism and economic, social, and political-administrative system of Iran have experienced significant changes [13]. Therefore, it necessitates an accurate study on water supply, determination of precise specifications of pollutant sources, codification of strategies and policies for prevention and control of water pollution and optimal use of the limited water supplies. Even quality of drinkable water supplies is affected by ambient conditions and pollutions caused by human activities, as under drought conditions and water shortage, the conditions for quality of water supplies are usually more critical. Likewise, concerning subterranean water supplies, discharge of urban and industrial wastewaters, landfill of disposals and penetration farming runoffs are assumed as the main pollution factors and in great agricultural zones, the side-effects consuming fertilizers and toxins are easily visible on underground water supplies. Therefore, in order to organize and improve the existing conditions for quality of water, it is necessary to evaluate and codify an applied plan for administration of quality of water supplies. Assessment of quantitative and qualitative status of water supplies and prevention from entry of pollutants into water is one of the foremost phases of planning and execution of water supply management [14] where during recent years this is assumed as a vital issue in developing nations and it aims to preserve public health and in addition to improving public participation in preservation of health and quality of surface waters, it proposes a helpful by giving proper image of qualitative condition of surface waters in order to make administrative decision with more awareness regarding the given environmental effects which affect directly or indirectly in national surface waters and to identify the necessity for implementation of administrative techniques for water supplies in line with protection from water and prevention from its contamination at any point [15].

\subsection{Water Proprietary Rights}

One of the essential topics posited for protection from water supplies is to determine what the status and structure of proprietorship of water supplies and whether this attachment of ownership to an identity may create an obligation for the owner for protection and conservation or only possessing of property is followed by the creation of right and power for the properties. Analysis of development trend for ownership of water is deemed as important vital because it realizes this point for us that how many types of proprietorship of this vital source has been efficient in our country. It is obvious despite the presence of private ownership over water supplies, the effects of their protection will be included in general rules of private ownership and if the property of these supplies 
follows public activities, the conditions for conservation and use as well as protection will be included in special terms of these rules. Both of aforesaid phases have been passed in our country and their executive effects are clear to us.

Enactment of the rules, particularly establishment of civil and criminal Performance guarantees regarding water supplies or installations is deemed as one of the most superior methods for protection from water supplies by any government or state. In addition to meet some of the public requirements for the community, water supplies are related to national, political, and defensive security of any country. Accordingly, taking a proper legal policy for protection from water supplies seems necessary for any country. The huge amount of investment by the governments in utilities of water supplies and construction and exploitation from them enforces the states to take measures, especially penal ones, to prevent the occurrence of utilization from these sources and to treat seriously against various motives intending to destruct or violate to such supplies [16]. Since the beginning of legislation, some of rules and regulations have been codified and approved within two frameworks relating to common law and constitution in this regard.

The Iranian Civil Code (approved in 1928) governed by Islamic legal system and Roman-German Laws has introduced waters as legal and possessive properties by the identities following to approval of Water Act and way of nationalization of water (in 1968) and in line with Islamic Jurisprudence and with such an approach it has determined principles and rules in the field of management, exploitation, and prevention from contamination.

The regulations governing over waters have followed generalities of Civil Code since enactment of social rules by legislators by 1968. In this period, public ownership of all water supplies i.e. general legal and common properties has been assumed as principle and any person could legally create the branch of water from brook or river and exploit from it [17].

According to Islamic logic, Civil Code assumes water as an exploitable public source for the public and considers it with proprietorship effects for the beneficiary person and any exploitation and dominance over water is deemed as permissible. Namely, anyone with full proprietorship right can use it for profit and based on it the others may not benefit from water supplies as public appurtenances unless the owner has personally determined objective or profit rights for them. Therefore, the rule of public common properties may be referable if water ownership has not been established for certain person.

Also regarding common public properties, Article 25 of Iran Civil Code acknowledges: "No one may take possession of property which serves the common good and which has no private owner, such as bridges, caravanserais, public reservoirs, ancient schools and public open places. And the same applies to the aqueducts and wells of which their use is public" [18]. In this article, the legislator not only forbids possession and monopoly of public properties all social strata need to them, but also considers the public use of these assets and antic- 
ipates right of utilization of water supplies for all members of the community, but this is continued to the extent not to lead to monopoly and absolute possession. Although he has not clarified limits of exploitation and way of utilization, to create right and obligations, he implies some generalities that elucidate source of the public use of water supplies. Then in Article 27 of this code, it defines the public legal properties. Likewise, as someone created water brook, ownership of water and stream would be determined for him. Therefore, the government or state did not own water supplies and all of the surface water supplies or otherwise could be used publically and anyone could benefit from them according to one's portion and no one could intrude or hinder use and utilization from water by the other. The principles governing over Civil Code including Article 30 of Civil Code holds in this regard: "Every owner has unlimited rights of Occupation and exploitation over his property in matters in which the law has made an exception" [18]. Hence anyone who has access to one of water resources by personal measures will own them and thereby he/she will have right to exploit from his/her property in whatsoever. Similarly, the references of Islamic law assume water as public wealth and property and right of public use has been expressed to all of people and it has been deemed as public properties. Islam argues that one of the general rights for the people is the right of human being toward all waters because the water falls throughout the land and this quality denotes that drinking and use of water is one of the general needs of humans and use of water will be free for all people. Articles 153, 155, and 156 of Civil Code introduces water as a natural phenomenon and public right and use of water is assumed as permissible for all of the people and there is no preference deemed for the exploiters and even in some cases it has been decided for equality as well as priority and preference of properties in order to make exploitation conditions close to justice.

Then, the act was approved concerning aqueducts on $28^{\text {th }}$ August and $6^{\text {th }}$ September 1930. Overall, the cases of aforesaid laws declare that anyone who intends to construct a well or water canal will be allowed to use legal advantages and special privileges for possession of properties of the third party if the others refuse. This rule is one of the complementary acts for Civil Code in which many rights have been assumed to applicants for construction of water canal and afterward the complementary law for Act of Aqueducts (approved on 14/09/1934) entered intolegislation phase. The same method has been adapted in this law similar to civil and previous rules and it has assumed specifically right of water for owners [19].

Following to the given rules, some of ordinary laws have been also ratified accordingly, whereas in 1943 the government showed inclination toward changing former regulations by enacting the relevant rules and regulations for irrigation corporation and gradually it has taken the power for administration of national irrigation activities in agriculture sector with developing process for water ownership that included the maximum operational range. Contents of the group of 
articles for amendment of law regarding an establishment of Irrigation Corporation may also suggest orientation of regulatory, executive, and operational rules and preservation of powers for owners in line with the development of corporation. Following to approval of this law, the corporation was allowed to conduct studies on water and application for ownership of the needed properties and thereby a new horizon opened to ownership of water supplies. Likewise, by taking approach toward leading owners to conducting the scientific activity and proper use of potential in lands, this law has determined some obligations for the private owners and anticipated sanctions. The powers of owners were reduced in final articles of this law and they were required to irrigate their land by utilities of corporation and allocate land plots and farm on them; otherwise, the land should be possessed by the corporation. This law has implicitly determined acquiring consent of owners as a condition for permission of water sale in private brooks and for this reason the corporation was assumed as a legal entity that followed Ministry of Agriculture and acted as an important irrigation factor [20].

Over the time, with respect to economic, social, and industrial conditions of the country, governmental intervention was increased in water supplies and Ministry of Energy was established at the early 1964 and policymaking was concentrated in a system for national water resources. The objectives for establishment of Ministry of Energy were mentioned in Article 1 of Bill for Act concerning the maximum use of water supplies and providing adequate electricity for consumptions in cities and villages and industrial and farming requirements of Iran. Given some of aforesaid goals listed in this article were followed by irrigation corporation or Tehran Water Organization or other enterprises in the past, their tasks were assigned in Article 2 of Act for establishment of Ministry of Energy [19].

Following to approval of Act for conservation and protection of national subterranean water supplies (approved on 22/05/1966) and establishment of Ministry of Energy, subject of preservation of national water supplies, which had been already determined by private owners at that time, was proposed by a new approach based on scientific and technical conditions. Pursuant to ratification of this act, supervision was followed by executive intervention and this became practical to prohibit exploitation by owners of wells and water supplies in the absence of conventional reasons and only based on scientific criteria to conserve waters. In Article 1 of this law, Ministry of Energy has been appointed for protection and preservation of underground water supplies and deposits and supervision over all of relevant activities and unlike the former trend in Article 3 of the same law, Ministry of Energy was permitted to make excavation of deep and semi-deep well and aqueduct to acquiring license where it discerns duly with prior notification [19]. The change arises from execution of this policy precisely refers to change of policy by the government since as government knows the exploitation from waters is not optimal therefore it has restricted preservation of private ownership of water supplies and made use of underground water sup- 
plies as subject to some conditions and circumstances. It is obvious this process is in conflict with theory of absolute proprietorship that permits total use of one's property but it complies with the principle which has been manifested in process of developing international law of environment as responsible and legal liability. In other words, in many cases Iranian domestic law is pioneer further than international law of environment. This trend proceeds to the point that it has been mentioned in Article 12 in case of breach of Articles 2 and 3 of this law, Ministry of Energy may prevent continuance of operation by referring of disciplinary officers to the given site and also beneficiary can complain against closing of operation [18]. Therefore, this change caused assigning suitable powers to Ministry of Energy that resulted in more appropriate protection from national water supplies.

By review on historical trend of water ownership laws and exploitation from water supplies since the beginning period of Constitutional Revolution through the date of approval of Water Act, about 38 regulations have addressed a subject of water directly or indirectly, they found that there is difference among water ownership and the right of utilization from it [21]. In this sense, Water Act and method of its nationalization was approved by legislator on 15/07/1968. The accurate criterion of this law is the creation of change by water nationalization as a national wealth and declaration of right of utilization to the public; the fundamentals for utilization from water were subject to changes within a new framework of planning and method of use and utilization from water. This trend exited ownership of water supplies from private mode and also required the government as an agent of community to organize exploitation from various water supplies in the country. Although term "National Wealth" has not been defined in this law it has been mentioned the water belongs to the public i.e. public ownership, these statements jointly denote cancellation of privileges for private ownership and creation of public ownership for the people. In this article, Ministry of Energy has been called as agent of community and responsible for physical, legal, scientific and technical protection from these sources and it is tasked with developing water supplies and construction and administration of the relevant utilities by planning.

Also the Islamic Republic of Iran Constitution (approved on 02/12/1979) has interpreted economic outlooks of Islamic government in Article 44 and 45 and laid the foundations of Iranian economic systems in three sectors i.e. governmental, private, and cooperative. In Article 44 of Iran Constitution, incumbency of water supplies and utilities has been considered by approach of optimal use by the governmental sector and also it has not overlooked other dimensions e.g. earning of revenue for the government toward economic and revenue-related objectives since the water supplies are vital according to various aspects. One can refer to shortage of water resources as some reasons to justify this issue because of necessity for public utilization from the given utilities and huge amount of investment in this sector as well as political and military goals paying attention to this point that not to assume water subject as a tool only for providing benefit 
for the limited persons. Article 45 is one of the other legal principles in Iran constitution. Two important issues have been considered in this article:

1) Most of the water supplies are included in public properties and wealth;

2) Islamic government is responsible for possession of them.

Although it seems the government can exclude these source from ownership and dominance of natural persons or legal entity by benefitting from the aforesaid article and in addition to preservation of public ownership for the public and then by assigning administration and exploitation from these sources to private sector as long as it does not damage their public ownership and to create revenue for them [22].

After the victory of Islamic Revolution and approval of Iran Constitution, regarding topic of water Act of Fair Water Distribution was ratified on 17/03/1983 following to Article 45 of Iran Constitution and the principles governing over economy sector.

Although despite the regulations of Water Act and method of its nationalization (approved in 1995), no requisite was seen for a new law with subject of water and irrigation, due to change in governmental structure and specific circumstances after Islamic Revolution and presence of contradictory paradigms to the former regime, Fair Water Distribution Act was approved in order to create regulations of fair water supply for all. Some points are noteworthy in Article 1 of this law:

1) It has been referred to types of water supplies in article;

2) By integration of regulations in Iran Constitution in relation with assuming water supplies as public properties, this article finely refers to regulations of Civil Code;

3) It has mentioned exploitation from them according to principle of public expediencies where this issue highlights that the water supplies have been introduced as possession of the public while the governments is deemed as reference for administration of utilities and also the government has been assigned for task of protection, permission, and supervision over exploitation from these sources.

It seems the government is responsible for activities regarding protection and preservation of various water supplies, although there is specific law concerning underground water supplies. Two points may be implied about permission and supervision overutilization from water supplies:

1) The government gives permission to the other for exploitation and it does not need to permission for occupation from another reference while the other are shared in these appurtenances they are not entitled to hinder protective or technical measures but they shall take permission from the government for intervention in water supplies or utilities as agent of community. Otherwise, their efforts will be assumed as illegal and unallowed and also a type of violence and deserving of punishment;

2) The Government will supervise upon exploitation and it can be inferred from the concept of this sentence that the government acts in both execution and supervision sectors. 
No other law has been ratified concerning general trend of water supplies by legislator after approval of Fair Water Distribution Act and presently this law is effective executively. From viewpoint of ownership of water supplies, some of executive procedures have been approved about Fair Water Distribution Act by the government such as procedure for determination of limit border and bed of rivers, brooks, floodgates, marshes and natural brooks approved on 03/07/1991 and procedure for limit of water utility tanks, public canals of irrigation and drainage approved on 15/07/1992 under subject of water supplies ownership.

\subsection{Water Pollution Law}

Environmental pollution is one of the bottlenecks to which today world is exposed and ignoring it may seriously threaten human life and survival but after several decades, the world, international, regional, and domestic concerns and even individuals have increased about effects of pollution on human health and natural resources. Such contamination emerges in the environment as consequence of human activities and it is followed by fundamentaltroubels on people's health [22]. Lack of appreciation for the environment and ignoring of necessity for purification and preservation of water may cause some abnormalities in numerous cases that are accompanied by mortality of many organisms, destruction of various nature effects and related constituents as well as various diseases which can threaten human health and life [23]. Different pollutants originating from point sources and non-point sources are carried by rivers to lakes, seas and oceans [24] [25] [26] [27]. Marine ecosystem are very susceptible to sea level rise along with a wide variety of pollutants, especially metals [28] [29] [30]. In other words, pollutants, especially metals has detrimental effect on environment [31] [32]. Surface water bodies as a key component of aquatic ecosystems are remarkably impacted by evaporation, evapo-transpiration, hydrology, global warming and climate change [33] [34]. Loss of Water resources, population growth, increasing demand for water consumption and generation of huge amount of wastewater has harmful effect on human society in case of poor water sustainable management and optimization for demand-supply and lack of high-productive varieties as well as draught resistant varieties [35].

Various definitions have been proposed about pollution in each of them some aspects of pollution have been considered. So far a perfect definition has been proposed by OECD organization in 1974. Based on this definition, pollution denotes entering materials or energy into environment directly or indirectly by human where it is risky for people's health and followed by hazardous effects to animal sources and ecosystems and damages water quality and creates obstacle against legal uses of environments. The criterion which has been assumed as parameter in the given definition is principle of detrimental effect of this practice for the environment and it covers subsequent losses in addition to immediate losses as well [36]. Alternately, environmental pollution denotes: "Any type of change in properties of environmental constituents so that their former uses be- 
come impossible and it threatens directly or indirectly interests and life of living organisms" [37].

Therefore, the pollution may be defined as change in environment, damage to human and their properties, and destructive intervention in rational uses of nature and increase in absorption capacity of the environment [38]. Environmental pollution is considered as the main goal in environmental regulations. What so far discussed in this law is what the human recognizes formally as pollution and how much it can be tolerated by human and other living organisms and what the task of human is versus this pollution [39].

The first definition, which has been proposed about environmental pollution is the one given in the Act of Protection and Renovation approved on 18/06/ 1974 and the rider dated 15/11/1992. After referring to prohibition of any environmental pollution in Article 9 of this law, it has defined pollution. According to attitude of this law, environmental pollution denotes dissemination or mixing of external materials with water, air or soil or the land to the extent that changes physical or chemical or biologic quality in such a way that to be hazardous to human or other living organisms and/or plants and or monuments and buildings [40]. Therefore, it can be observed that regardless of the used definition and the terminology in that law, this definition is conceptually is the same as definition expressed by environmental specialists about pollution. In other words, legal definition of environmental pollution is not separated from the given expert definition. The aforesaid definition has been mentioned with some few changes in provision 2 of Article 688 of Islamic Punishment Act approved on 22/05/1996 and with the subsequent amendments on 21/04/2013. The given provision holds that the environmental pollution declares: "Propagation or combination of external materials with climate or soil or the land to the extent that alters physical or chemical or biologic quality in such a way that to be hazardous to human or other living organisms and/ or plants and or monuments and buildings" [41]. Similarly, it has been mentioned in Article 1 of executive bylaw of Clause III of Article 104 of Third National, Economic, Social, and Cultural Development of Islamic Republic of Iran approved on 17/03/2001 with its amendment dated 21/05/2007 that definition of pollution is the same as the aforesaid definition in Article 9 Act of Environmental Protection and Renovation [40].

In some Iranian laws and regulations, environmental pollution has been mentioned generally while in some other regulations the subject of contamination of environmental elements either animated or unanimated has been separately implied. The environmental pollution includes several areas and forms among of them the water pollution has particular importance and position and it has been addressed more in domestic and international rules and regulations than other cases. The law in which it has been explicitly mentioned about subject of pollution is Act of Water and method of its nationalization approved on 03/07/1968 where Article 60 of the given law is concerned with intentional pollution of water in river, public canals, brooks, tanks, supplies, aqueducts, and wells by addi- 
tion of external substances and water pollution has been assumed as prohibited and a crime. According to Article 11 of Act of Protection and Renovation (approved on 18/06/1974) and its rider (dated 15/11/1992), the organization should stop the activity of the owners or authorities of factories and workshops in which they do not take measure to remove the pollutant factors within the stipulated deadline. One of the other rules in which water pollution has been declared as prohibited may be Act of Fair Water Distribution approved on 07/03/1983. In Article 46 of the law as mentioned earlier, water pollution has been addressed briefly in an article and declared water pollution as prohibited and it has introduced environmental protection organization as responsible for prevention and stopping of water pollution and assigned the task of codification and follow-up the relevant procedure to the given organization. Bylaw described above, in the session held by Board of Ministers on 08/05/1994 and as per proposal No 21-867 dated 16/08/1993, environmental protection organization ratified procedure regarding prevention from water pollution. According to Clause 3 of Article 1 of given bylaw water pollution is defined as followed: "Water pollution means change in soluble and or suspended materials and or in temperature and other physical and chemical and biological properties of water to the level that it converts water into hazardous or useless for the stipulated consumption of water" [40]. It should be noted that the water pollutant sources include all types of supplies their activity or exploitation may lead to water contamination comprising of industrial, mineral, agricultural and animal husbandry, urban and homemade, servicing and medical and miscellaneous sources. Of course, water pollution may be intentional or unintentional, in any case, pollution of water is forbidden. Some of the side-effects of water may be immediately identified while some others may last for several months or a few years [23]. In Clause 4 of water pollution prevention bylaw, the water pollutant substances are introduced as follows: "Any type of materials or physical and chemical and biologic factors which cause water pollution or add to the pollution" [40]. Based on the given definitions, it is concluded that the water pollutant materials may be physical or chemical or biologic. The pollution causes may be provided by a change in temperature and other physical, chemical, and or biologic properties and if they exceed from some level they make the water hazardous or useless for the stipulated consumption and pollution is realized. What is clear is that the water may be also indirectly used in for some goals in consumption cycle. The studies express that the majority of water supply is used in the agriculture sector and the resulting products are used directly or indirectly by human.

It should be mentioned that the major part of water supplies are fed in farming areas as well as flowing through natural resources. Concerning a lot of consumption of pollutants and toxins in agriculture and national lands, although they may not be hazardous for production of target crop, the resulting crops act as factor for transferring some of pollutants and toxins to other chains of consumption cycle and they are followed with adverse consequences for the human. 
Therefore, it is better to increase the range of targeting for definition of pollution about the final objective of consumers. Given the aforesaid cases and Clause 5 of bylaw for prevention from water pollution, it is mentioned about pollution productive sources: "Any type of source in which the activity or exploitation causes water pollution including industrial, mineral, agricultural and animal husbandry, urban and household, servicing and medical and miscellaneous sources" [40]. Likewise, Clause 13 of the given article of this bylaw introduces prevention from water pollution as responsible for introducing a natural person that is in charge of administration or incumbency for pollutant sources such as factories, workshops, and other industrial installations either for personal use or by acting as agent for other natural persons and/or legal entities or personally act to create pollution factor in various forms [40]. Presently if all of the given definitions and especially final part of Clause 13 of Article 1 of the aforesaid bylaw are more addressed, it is characterized that if the measures taken in areas of natural and farming sources and under the title of fighting against pests and diseases are not compliant with standards they are included in this pollution and pollutant agent will be responsible whether owner or incumbent or exploiter. Then, based on Article 2 bylaw regarding prevention from water pollution, doing of activities by which the ground is prepared for water pollution is declared as prohibited. Therefore, those persons who discharge any type of trashes into waters and create hazardous changes in waters by execution of mineral activities are assumed as polluters and liable and in Article 9 of given bylaw is concerned with subject of liability and it creates opportunity to remove pollution and it even determines additional deadline suitable for removal of pollution provided it is not followed by serious risks for human health and other living organisms. Similarly, concerning cumulative effects of pollutants, this responsibility becomes more extensive and also the standard level of pollution will be reduced. Environmental protection and optimal use of national natural resources may be realized according to Act of $2^{\text {nd }}$ Iran Economic, Social, and Cultural Development Plan (approved in 1995) in light of prevention from environmental pollutions, particularly pollutions in surface and underground water as well as marine environment and this subject has been also emphasized in provision 83 of the given law about removal of pollution from water supplies. Likewise, it has been implied in Clause III of Article 104 of $3^{\text {rd }}$ IR Economic, Social, and Cultural Development Plan (approved on 05/04/2000) that in order to reduce environmental pollutants, especially regarding natural resources and national water supplies, the production units shall take measure to adjust their own technical specification to criteria of environment and reducing pollutions and based on Clause III of Article 192 of $^{\text {th }}$ IR Economic, Social, and Cultural Development Plan (approved on 05/01/2011), implementation of great production projects and plans should be adjusted in line with reduced pollution of natural resources and water resources.

\subsection{Water Protection Law}

Water is assumed as one of the most original vital elements in the life cycle for 
all animals including human. For this reason, even before coining of terms "environment" and "environmental law", subject of prevention from water pollution has been proposed typically in all human communities and the earliest environmental rules were formulated in this regard and any country became liable for protection from their own water supplies. For this reason, legislator determines sanctions to guarantee for enforcement of criteria to protect it along with supportive policies in this domain [42]. The sanction is the power used for enforcement of law or court decision and it is reaction of law versus breach of a legal order. In other words, sanction is an order to guarantee for proper implementation of regulation to achieve the existent goals and objectives of that criterion. Thus, legislator should be careful in this regard at the highest level. In codification and approval of rules and regulations, legislator supposes that the approved law is not executed by individuals and for thus reason, he also considers some punishment for the violator. Of course, it noteworthy that the essence of law is namely the best sanction for its enforcement. The obvious point in sanction is that the sanction differs in any field of law and rules and those various forms are not at the same level concerning intensity and weakness. Likewise, in silent cases of law versus sanction for definite breach, the appropriate case of that violence should be selected among different forms [43]. Thus, along with supportive policies for environmental domain, legislator determines sanctions to guarantee for enforcement of protection from this subject, including:

1) Criminal Sanction

Among types of sanction, criminal sanction plays efficient role in the creation and internalizing environmental values and even the necessity for criminal protection has been demonstrated as environmental constituent elements in foreign published works [44]. The criminal sanction may control the behaviors and thus produce values and norms by determination of punishment in order to assume the policies and strategies governing over social, political, and economic issues and their observance as valuable and necessary for the community [45]. At present, a subject which should be addressed is that what type of criminal sanction has been determined and stipulated for supporting and protection from aquatic environment and if the given sanctions are appropriate and efficient. The competent courts of justice are responsible for enforcement of criminal sanctions and judicial references may change them by means of some cases e.g. amnesty, suspension, and mitigation of punishment. On the other hand, the anticipated fluctuations in sanctions are contextual since the aforesaid references consider various sanctions for environmental crime in the field of protection from water in terms of quantity and quality of them to the extent that the stipulated sanction in that order may not probably meet the objective considered by legislator in determination of sanction. Therefore, the carefulness of courts in selection and use of quantity and quality of the criminal sanctions are very important in the issued awards. For example, determination suitable sanction for some of environmental crimes in aquatic field in the issued decisions may con- 
tributes the community to achieve goal of supporting and protection from aquatic environment and prevention from entry of pollution into water, but if unsuitable sanction is selected it has this potential to prepare the ground for repetition of environmental crimes against aquatic field and causes the activity of pollutants and entry of environmental pollutions to be continued.

Based on Clause IV of Article 12 of Act regarding Hunting and Fishing (approved on 06/06/1967) with the subsequent amendments, pollution of water of rivers, lakes, and preserved lagoons, springs, and watercourses that are led to water pollution as well as removal of aquatic creatures has been assumed as crime and the perpetrator will be sentenced to incarceration and or payment of cash fine. Similarly, in Article 60 of Act of Water and its Nationalization (approved on 03/07/1968), the legislator has benefitted separately from both punishments of confinement and cash fine and also in some cases jointly to respond to environmental crime of water pollution and some circumstances when water pollution was committed for fighting against the Islamic Republic of Iran, the culprit will be tried in Revolutionary Court. In Article 12 of Act for Protection and Renovation (approved on 18/06/1974) and its rider (dated 15/11/1992), the punishment of incarceration and cash fine have been stipulated for the officials of factories and workshops that provide environmental pollutions. Then, as per Article 22 of bylaw for protection from water pollution (approved on 08/05/ 1994), if breach of regulations in this bylaw causes any damage in the environment for aquatic creatures and natural resources, the court will sentence the responsible perpetrators to payment of fine and compensation for the incurred losses [40]. On the strength of Article 9 of Act for protection from seas and inland rivers against oil pollution (approved on 08/09/2010), pollution of waters of marine regions is forbidden as subject of IRI zones in Persian Gulf and Oman Sea (approved on 20/04/1992) and the waters under Islamic Republic of Iran sovereign state in Caspian Sea and inland rivers and perpetrator or perpetrators will be sentenced to confinement or payment of cash fine or both punishments as criminal response. Of course, if pollution is created due to carelessness or negligence, the minimum punishment of perpetrator is payment of cash fine. In Article 688 of Islamic Punishment Act (approved on 22/05/1996) with the subsequent amendments (dated 21/04/2013) also sentence the perpetrator of crimes for water pollution to incarceration. Likewise, in Article 104 of $3^{\text {rd }}$ Iran Economic, Social, and Cultural Development Plan (approved on 05/04/2000) it has been mentioned that those units which do not take measure to reduce pollution and their activities cause pollution, the cash fine will be received from them proportional to the incurred damage and in Clause II of Article 192 of $5^{\text {th }}$ IR Economic, Social, and Cultural Development Plan (approved on 05/01/2015) it assumes punishment of law-breakers in creating environmental pollution as included in Article 30 of Act regarding quality of prevention from air pollution (approved on 23/04/1995); namely, it has stipulated cash fine and confinement for them.

2) Civil sanction 
The civil sanction refers to those classes of sanction which require polluter to compensate for the given losses to environment. This sanction may compel the polluter to compensate for the exerted damages to the environment by different methods such as returning environment to the former status (returning the original elements of environment or the given examples such as plant and animal etc. or destruction of damage source) and also giving equivalents (compensation by similar element and paying price).

Of course, regarding environmental damages, the exerted loss is compensated mainly by paying price. Although in this way one could not really compensate for exerted damage to the environment, in any case there is no solution for compensation of a part of damage except resorting to this method and payment of cash fine since at least some part of the given damage is compensated and or it can be used for renovation and strengthen the other part of environment [46].

Article 45 of Act for Fair Water Distribution (approved on 07/03/1983) refers to compensation of exerted loss by returning it to the former status. Based on this article, if anyone deliberatively wastes the water to create loss for the other person and usurps right of water of the other person without legal permission and excavates well and or aqueduct without observance of this law and or exploits from water supplies and or interrupts in exploitation from water utilities, he shall compensate for the exerted losses in order to return it to the former status [40].

\section{3) Administrative sanction}

All activities which are typically involved in governmental, public or administrative institutions such as issuance of permission and license of activity as well as standards, stopping activity of pollutant units to prevent from the further damage to the environment and activities of this kind and also way of performance of systems in treating with the law-breakers are considered as examples of administrative sanctions. It should be implied that the subject for addressing administrative violations of governmental personnel and public institutions are investigated. The legislator has enacted some rules and regulations in the field of environmental protection and appointed some organizations to enforce it [47].

Based on Article 46 of Act for Fair Water Distribution (approved on 07/03/ 1983), the primary responsibility for prevention, stopping, and avoidance from water pollution is assigned to environmental protection organization unless another organization is responsible for this task according to specific law and in execution of this task, based on Article 4 of bylaw for prevention from water pollution (approved on 08/05/1994), this organization may benefit from cooperation with Ministry of Energy, Ministry of Agriculture, Ministry of Health and Treatment and Medical Training, and other ministries and relevant organizations as required and prepare the standards relating to water pollution and recognize and analyze quality of waters. By virtue of Article 7 of bylaw for prevention from water pollution, if the organization samples the wastewater and the surplus solid materials of pollutant sources and the intensity of pollution is higher the standard level in each of pollutant sources, it notifies the cases to the 
relevant official in written to take measure for removal of pollution and in this warning, type and quality of pollution as well as deadline for removal of pollution will be determined proportional to the facilities and explicitly expressed and if responsible official for pollutant source proves it by presentation of reasonable causes and evidences that removal of pollution is not practical within the stipulated deadline, according to Article 9 of the given bylaw, the organization may assume additional deadline for them. Of course, this point should be kept in mind by that organization continuance of activity of pollutant source not to be followed by serious risk for human health and other living organisms. Similarly, environmental protection organization will be responsible for the prosecution of pollutant factors to waters of seas and boundary and domestic rivers in all cases except oil pollution and or any type of oil mixture.

Concerning prevention from the entry of pollution in water, municipalities possess comprehensive and detail project to construct canals to lead surface and underground waters. Absence of such canals may cause wastewaters to enter into drinking waters and pollute them; and on the other hand, lack of proper system for transferring surface and subterranean waters will cause these waters to flow into city and rather than creating ugly and unpleasant landscapes, they are led to environmental pollution and dissemination of various diseases. To do this task in some cities where there are not canals to lead waters and wastewater system and in order to prevent from flowing of wastewater through the cities, municipalities create underground reservoirs in some urban zones and lead surface waters and wastewater into these tanks. Then they pump these waters into the tanks of some specific vehicles and carry them outside the city. Qom municipality has already done this task in this way. It should be implied that the municipality behaves seriously with those persons who throw away their wastewaters of their homes [47]. Article 13 of bylaw for prevention from water pollution (approved on 08/05/1994) has required municipalities to observe standards and regulations relating to water pollution and wastewater upon issuance of construction license when preparing comprehensive projects for residential and healthcare townships and complexes as well as municipalities and inform it to designers, executives, and owners. Under Clause 20 of Article 55 of Municipality Act (approved on 03/07/1955), the municipalities may seriously treat with the water polluters and issue order to close, demolish, and or transfer them outside the city any type of industrial unit that causes water pollution [40].

One can refer to other organizations which are involved in prevention from the entry of pollution into water e.g. Ports and Maritime Organization and it was converted into Ports and Shipping Organization since July 1950. Along with its major function, this organization also acts in the environmental area. One of the tasks of this organization is fighting against pollution of Iranian waters and in this regard there is an administrative organization called "Maritime Activities Administration" and this department prepares and analyzes the reports concerning the reasons for marine accidents and pollution of water based on the data received from the ports and these reports are efficient in way of decisions 
made by the authorities of this organization. Similarly, the given organization also prepares the needed instructions for way of tackling with fire accidents and pollution of sea water etc. There is also another department for fighting against pollution of Iranian waters called "Marine Guarding Administration" where some tasks for which this department is responsible include planning and making the required policies for surveillance and rescue and prevention and fighting against pollution and the accidents occur in littoral and territorial waters of Iran for which this department also suggests about codification, development, and completion of the needed rules and regulations regarding removal of pollution, surveillance, and rescue and marine accidents. Likewise, this department conducts the needed follow-up measures concerning preparation and the needed equipment for ports regarding surveillance and rescue and pollution of marine zone and accidents rather than giving a suggestion as well [47]. The Act of protection from seas and inland rivers against oil pollution was ratified on 08/09/ 2010 and it has been stipulated in Article 9 of this law that it is forbidden to pollute waters as subject of this law (the marine zones as subject of the Islamic Republic of Iran Regions Act in Persian Gulf and Oman Sea approved on 20/04/ 1992 and also the water under the Islamic Republic of Iran sovereignty state in Caspian Sea and inland rivers) and perpetrator or perpetrators will be sentenced by anticipated punishment for them in law i.e. incarceration or cash fine and often both punishments may be applicable. Likewise, based on Article 11 of the given law, Ports and Maritime Organization shall communicate with military and disciplinary forces to take the needed measures by giving information and to prevent from expansion of pollution and removal of their side-effects. Some of the other tasks of Ports and Shipping Organization include drawing up minutes for estimation of level of pollution and collection of causes and evidences and proofs relating to reasons of occurrence and effects of pollutions in order to assess rate pollution and the exerted damages to the environment and deposits of aquatic creatures through cooperation with environmental protection organization and Iranian Fishery Organization and their affiliates. Taking legal action against the polluters in judicial references is one of the other tasks for this organization.

The water and wastewater organization is the other responsibly authority for protection from water. As it mentioned in Article 1 of Act for establishment of water and wastewater companies (approved on 01/01/1991), tasks of construction and exploitation from facilities of urban water distribution and also collection, transfer, and treatment of wastewater in cities within the legal limit of cities at any province are assigned to an independent company called Provincial Water and Wastewater Company that will be established by Ministry of Energy [40].

Ministry of Health is responsible in the field of protection from drinkable water. Based on bylaw of environmental health (approved on 15/07/1992), the goal of establishment of the committee for protection from drinking water supplies is implied as avoiding from growing trend of pollution of surface and underground water supplies including wells, rivers, aqueducts, springs, and consuming waters 
in city and village that is held under supervision of province governor with membership of directors and heads of health and treatment and medical training administration, environmental protection organization, provincial regional water organization, provincial construction Jihad organization, state management and planning organization, and Water and Wastewater Company of the province in order to deal with some cases to review them for execution as follows:

1) Making decision about exclusion of some of drinking water supplies from services which have been polluted according the report of environmental health administration such as wells, springs, and aqueducts;

2) Taking the needed measures to protect from the existing drinking water supplies based on instructions suggested by the relevant references and approved by this committee;

3) Making the needed efforts to protect from territory of the zones which are offered for providing water to cities by the relevant references in the future;

4) Making decision about the crises caused by pollution of water supplies and way of tackling with them. Likewise, it has been implied in provision 1 of Article 3 of bylaw for prevention from water pollution (approved on 08/05/1994) that the Ministry of Health and Treatment and Medical Training will according the related rules and regulations concerning the drinking waters from water collection phase [40].

\section{Results}

Protection and guarding of water supplies has started since long time ago and it has drawn attention by the government about ever-increasing need to water and its shortage and population growth as well as the high threshold of water vulnerability versus various types of pollutants.

The importance of subject of protection from water supplies and prevention from entry of pollution and role of water in production and consumption chain and human health and environment as well as their relevance to ownership of water supplies may require for conducting extensive researches in this field; as a result, to protect human health and aquatic environment as possible. Based on the role of ownership in administration of water supplies the legislator has been coerced to try to correct and optimize the laws proportional to the existing conditions so that the law to be necessarily effective and to prevent the conflicts caused by private ownership over the water supplies. Likewise, concerning water pollution, with respect to ever-increasing growth of population, development of industry, and requirements for rising production on unit of area, it necessitates for revision of the existing rules and regulations. What it seems as important about water pollution relates to the resulting risks to the environment and human health. In some cases, water pollution is to the level that is vitally lethal. The foremost legal challenges existing in the field of protection from water and prevention from its pollution are as follows:

1) Absence of comprehensive law and dispersion of the existing rules and reg- 
ulations in various fields of waters:

During several years, no law has been so far approved in the existing rules and regulations in Iran under the title of "Act of Clean Water" and at the same time there is no independent law regarding prevention from water pollution. Therefore, in order to investigate about water pollution, one should attribute to several rules and regulations. Approval of a comprehensive law that covers local and global solutions regarding protection from aquatic environment and the knowledge of experts has been utilized in codification of this law may be efficient in rate of effectiveness and rising capability of sponsor systems in supporting from goals of protection of water and prevention from pollution and strengthening inter-sectorial cooperation as one of the necessities governing over subject of protection from aquatic environment.

2) Mild punishment and downgraded role of judicial system in prevention from water pollution:

The punishment which are enforced against crime of water pollution in Iranian criminal system are some of the mildest punishments and legislator has often employed cash fine punishments that are typically easier for the criminal to fulfill them and restorative punishments have been less addressed such as requirement of renovation and reconstruction of destruction. It is natural that payment of cash fine is easier especially for the great companies and wealthy persons who actually play the greatest role in creating environmental aquatic pollution. Regardless of this point that taking of cash fine is not proportional to value of the damaged environment, lack of proportion of level of such punishments with intensity of environmental crimes may seriously reduce deterrence of criminal system for environment. Of course, lack of familiarity of authorities and officials with aquatic environment and absence of appropriate and favorable trainings upon their utilization, lack of the needed solidarity in tasks and mission of responsible references and shortage of the suitable scientific sources for prevention from water pollution has weakened criminal system for Iranian environment. Similarly, given that delay in addressing and issuance of order regarding environmental cases may lead to further damage to environment, the legal cases for crimes against environment should be addressed out of ordinary process in justice courts and done by magistrate's offices and arbitration councils.

3) Improper cultural attitudes toward aquatic environment:

Surely, the main root of most of improper behaviors against aquatic environment may be returned to cultural factors including lack of awareness of the risky consequences caused by environmental aquatic pollution. The environmental protection organization is the main reference for presentation of such trainings and upgrading cultural level in society in treating with aquatic environment properly. Of course, role of other cultural organizations should not be ignored e.g. schools, universities, Ministry of Culture and even establishment of NonGovernmental Organizations (NGOs) in this regard. 
It necessitates for a suitable strategy in order to achieve educational objectives with respect to requirements and preferences in the community. Codifying two long-term and short-term strategies may prepare the ground for upgrading level of environmental awareness in the society. It needs to revise and review the curricula in long-term strategy and to study comprehensively on modern educational and learning techniques of environmental subjects in other countries and to design and execute a plan at different educational levels in order to implement efficient and effective methods in compliance with our Islamic culture as well and to deal with solving the current problems in the short-term strategy and coordinate the plans with goals of long-term strategy in short time.

In order to achieve the comprehensive result from educational projects, it should be dealt with recognizing educational requirements for all of target-dependent groups including several educational levels and after determination of applied parameters and priorities, it should be tried to prepare basic grounds for enhancement of environmental awareness and use of combinatorial techniques and cooperation by other relevant organizations and institutions as well as inter-sectorial coordination. Thus one can hope to achieve excellent objectives for protection from aquatic environment and prevention from creating pollution in them.

\section{Discussion and Conclusions}

During recent decades, the relationship among development level of communities and rate of achievement of environmental standards and namely observance of environmental considerations have been highly noticed by the researchers. Protection from aquatic environment and prevention from water pollution is one of the subjects which have been devoted to several studied fields. Based on the current study, some solutions are presented to remove the existing legal challenges in the field of protection from water and prevention from water pollution as follows:

1) Approval of comprehensive and integrated national water law and employing experts and specialists in codification of law by participation of all the relevant practitioners and beneficiaries based on management of water demand proportional to time and place;

2) Making regulatory and follow-up units of aquatic environment more effective in the related environmental organizations;

3) Correction of attitude taken by the relevant officials toward principle of participation in long-term and short-term planning in the environmental aquatic fields and accurate identifying of the culture and norm of the given community and using it for creating participation;

4) Presentation of appropriate trainings to the judges and other personnel of judicial and executive references regarding criminal protection from aquatic environment;

5) Upgrading public training and awareness about aquatic environment; 
6) Establishment of Non-Governmental Organizations (NGOs) throughout the country to prevent from violation and transgression to water supplies.

According to the conducted investigations in this field, it is hoped that to interpret and explain position of protection from aquatic environment and prevention from entering pollution into water supplies and to assume the water as a deposit which should be reserved as rights for the future generations in addition to exploitation from water supplies.

\section{References}

[1] Etemadi, S.Y. (2004) The Development Trend of Rules of Natural Resources and Environment. Behnami Press, Tehran.

[2] Heidari, F. and Heidari, M. (2015) Effectiveness of Management of Environmental Education on Improving Knowledge for Environmental Protection (Case Study: Teachers at Tehran's Elementary School). International Journal of Environmental Research, 9, 1225-1232.

[3] Ghorbani, M. and Zare, A. (2010) An Introduction to Environmental Evaluation. 2nd Edition, Mashhad University Press, Mashhad.

[4] Anderson, B., Romani, J., Wentzel, M. and Phillips, H. (2010) Awareness of Water Pollution as a Problem and the Decision to Treat Drinking Water among Rural African Households with Unclean Drinking Water: South Africa 2005. Population Studies Center Research Report 10-701, University of Michigan, Institute for Social Research, Ann Arbor.

[5] Jonoubi, R. (2016) Pollution of Water Supply Extraction and Method of Prevention. Rural Water and Wastewater Company, Azarbayejane Gharbi.

[6] Ziba Kalam, S. (2016) How We Became Us. 27th Edition, Rozaneh Press, Tehran.

[7] Ediger, W. (1997) Wasser als Naturlicher Rohstoff. In: Barandat, J., Ed., WasserKonfrontation Oder Cooperation: Okologische Aspekte Von Sichrheit am Beispiel eines Weltweit Begehrten Rohstoff, Baden, 27-52.

[8] Mays, L.W. (1996) Water Resources Handbook. McGrow-Hill, New York.

[9] Shiklomanov, I. (1993) World Water Resources. In: Gleick, P., Ed., Water in Crisis, Oxford, New York.

[10] Madani, K. (2014) Water Management in Iran: What Is Causing the Looming Crisis. Journal of Environmental Studies and Science, 4, 315-328. https://doi.org/10.1007/s13412-014-0182-Z

[11] Caponera, D.A. (1992) Principles of Water Law and Administration-National and International. Rotterdom, Brookfield.

[12] Teclaff, L.A. (1996) Evolution of the River Basin Concept in National and International Law. National Resources Journal, 36, 359-391.

[13] Water Planning Office (1998) Analysis on Status of Water Sector in National Planning System. Water Affairs Deputy of Ministry of Energy, Tehran.

[14] Moridi, A., Krachian, R. and Zakaiee, M. (2016) Analysis on Status of Quality of Iranian Water Supplies (Period: 2004-2014). Journal of Studies of Iranian Water Supplies, 12, 23-35.

[15] Torabian, A., Hasani, A.H. and Karbassi, A.R. (2008) Review of the Problems to Formulate Parameter of Quality of Water in Iran. The First International Conference on Water Crisis, Zabol.

[16] Naghdi Badi, A. (2016) Law Waters. Fakhteh Monthly, No.126. 
http://www.iranlawclinic.com/writing/

[17] Jafari Langroudi, M.J. (2001) Law of Properties. Ganje Danesh Press, Tehran.

[18] Moosavi, S.R. and Afshar, B. (2015) Civil Code along with Special Civil Rules and Votes of Uniform Practice. Hezar Rang Press, Tehran.

[19] Legal Office of Ministry of Energy (1994) Collection of Rules of Hydroelectric Industry. Ministry of Energy Press, Tehran.

[20] Legal Office of Ministry of Energy (1994) The Amended Law for Act of Establishment of Irrigation Corporation and the Relevant National Irrigation Activities Approved on 03/08/1955. Ministry of Energy Press, Tehran.

[21] Sormeh, M. (1989) Water Law. Vol. 1, Sekeh Press, Tehran.

[22] Hashemi, S.M. (1995) Islamic Republic of Iran Constitution. Vol. 1, Beheshti University Press, Tehran.

[23] Khan, M.A. and Mujahid Ghouri, A. (2011) Environmental Pollution: Its Effects on Life and Its Remedies. Journal of Arts, Science \& Commerce, 2, 276-285.

[24] Karbassi, A.R., Heidari, M., Vaezi, A.R., Valikhani Samani, A.R., Fakhraee, M. and Heidari, F. (2013) Effect of $\mathrm{pH}$ and Salinity on Flocculation Process of Heavy Metals during Mixing of Aras River Water with Caspian Sea Water. International Journal of Environmental Earth Sciences, 72, 457-465. https://doi.org/10.1007/s12665-013-2965-Z

[25] Karbassi, A.R., Bassam, S.S. and Ardestani, M. (2013) Flocculation of Cu, Mn, Ni, $\mathrm{Pb}$, and $\mathrm{Zn}$ during Estuarine Mixing (Caspian Sea). International Journal of Environmental Research, 7, 917-924.

[26] Karbassi, A.R., Fakhraee, M., Heidari, M., Vaezi, A.R. and Valikhani Samani, A.R. (2014) Dissolved and Particulate Trace Metal Geochemistry during Mixing of Karganrud River with Caspian Sea Water. International Arabian Journal of Geosciences, 8, 2143-2151. https://doi.org/10.1007/s12517-014-1267-4

[27] Vaezi, A.R., Karbassi, A.R., Habibzadeh, S.K., Heidari, M. and Valikhani Samani, A.R. (2016) Heavy Metal Contamination and Risk Assessment in Riverine Sediments. Indian Journal of Geo-Marine Sciences, 45, 1017-1023.

[28] Fakhraee, M., Karbassi, A.R., Vaezi, A.R., Heidari, M. and Bashiri, A. (2015) An Investigation on Flocculation, Adsorption and Desorption Process during Mixing of Saline Water with Fresh Water (Caspian Sea). Journal of Environmental Studies, 41.

[29] Valikhani Samani, A.R., Karbassi, A.R., Fakhraee, M., Heidari, M., Vaezi, A.R. and Valikhani, Z. (2014) Effect of Dissolved Organic Carbon and Salinity on Flocculation Process of Heavy Metals during Mixing of the Navrud River Water with Caspian Seawater. Journal of Desalination and Water Treatment, 1-9.

[30] Zou, T. and Zhou, Z. (2013) Urban Surface Water System in Coastal Areas: A Comparative Study between Almere and Tianjin Eco-City. Open Journal of Ecology, 3, 407-416. https://doi.org/10.4236/oje.2013.36046

[31] Karbassi, A.R. and Heidari, M. (2015) An Investigation on Role of Salinity, pH and DO on Heavy Metals Elimination throughout Estuarial Mixture. Global Journal of Environmental Science and Management, 1, 41-46.

[32] Vaezi, A.R., Karbassi, A.R., Fakhraee, M., Valikhani Samani, A.R. and Heidari, M. (2014) Assessment of Sources and Concentration of Metal Contaminants in Marine Sediments of Musa Estuary, Persian Gulf. Journal of Environmental Studies, 345360.

[33] Bartolai, A.M., He, L., Hurst, A.E., Mortsch, L., Paehlke, R. and Scavia, D. (2015) Climate Change as a Driver of Change in the Great Lakes St. Lawrence River Basin. 
Journal of Great Lakes Research, 41, 45-58. https://doi.org/10.1016/j.jglr.2014.11.012

[34] Kiani, T., Ramesht, M.H., Maleki, A. and Safakish, F. (2017) Analyzing the Impacts of Climate Change on Water Level Fluctuations of Tashk and Bakhtegan Lakes and Its Role in Environmental Sustainability. Open Journal of Ecology, 7, 158-178. https://doi.org/10.4236/oje.2017.72012

[35] Alimohammadi Nafchi, R. (2017) Evaluation of Wastewater Quality Compared to Well Water in Irrigation. Open Journal of Ecology, 7, 271-278. https://doi.org/10.4236/oje.2017.74018

[36] Karimi Pour, Y., Golkarami, A. and Hosseini, S.M. (2014) Geopolitics of Legal Gaps for Combating Marine Pollution. Journal of Majlis and Rahbord, 83, 179-202.

[37] Dabiri, M. (1996) Environmental Pollution. Etehad Press, Tehran.

[38] Pour Nouri, M. (2003) Environmental Law of Sea. Vol. 1, Cradel of Law Press, Tehran.

[39] Copeland Nagle, J. (2009) The Idea of Pollution. University of California, Davis, School of Law Review, Vol. 43, No.1. http://www.lawreview.law.ucdavis.edu/issues/43/1/articles/43-1_nagle.pdf

[40] Legal and Parliamentary Office and Environmental Protection Organization (2004) The Collection of Rules and Regulations for Environmental Protection and National Comprehensive Excellence. Legal and Parliamentary Office and Environmental Protection Organization.

[41] Moosavi, S.R. and Moosavi, S.A. (2015) Islamic Punishment Act. 2nd Edition, Hezar Rang Press, Tehran.

[42] Saed, M.J. (2009) Criminal Protection from Environment. The Collection of Essays on Environmental Law (Theories and Procedures). Khorsandi Press, Tehran, 117138.

[43] Heidari, F. and Heidari, M. (2015) Requirements of Criminal Environmental Law. First International Congress on Environment, Tehran.

[44] Faure, M.G. and Visser, M. (2003) Law and Economics of Environmental Crime: A Survey. https://www.aic.gov.au/publications/Proceedings/26/pain.pdf

[45] Pain, N. (1993) Criminal Law and Environmental Protection-Overview of Issues and Themes. Proceeding of a Conference on Environmental Crimes, 1-3 September 1993, Hobart. http://www.aic.gov.au/publications/Proceedings/26/pain.pdf

[46] Ghasemi, N. and Heidari, F. (2011) The Study of Civil Liability Caused by Environmental Damages. Journal of Law \& Politics Research of Allameh Tabatab'i University, Faculty of Law \& Political Science, 34, 377-400.

[47] Heidari, F. (2010) The Study of Civil Liability Caused by Environmental Damages in Iran's Law. M.S Dissertation, Islamic Azad University, Tehran Science and Research Branch, Tehran. 
Submit or recommend next manuscript to SCIRP and we will provide best service for you:

Accepting pre-submission inquiries through Email, Facebook, LinkedIn, Twitter, etc. A wide selection of journals (inclusive of 9 subjects, more than 200 journals)

Providing 24-hour high-quality service

User-friendly online submission system

Fair and swift peer-review system

Efficient typesetting and proofreading procedure

Display of the result of downloads and visits, as well as the number of cited articles Maximum dissemination of your research work

Submit your manuscript at: http://papersubmission.scirp.org/

Or contact gep@scirp.org 